\title{
SOEP
}

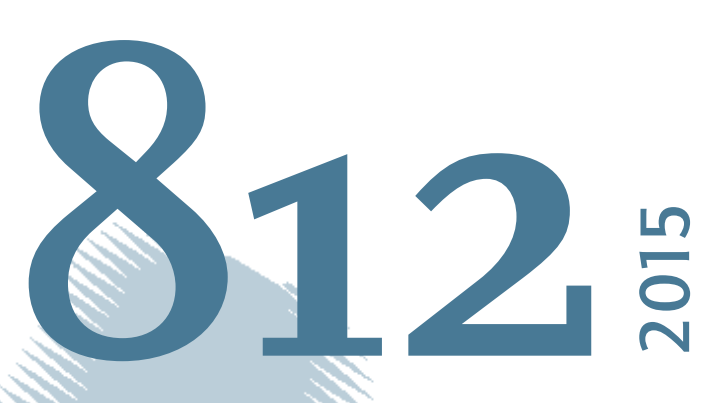

SOEPpapers

on Multidisciplinary Panel Data Research

\section{Beyond the Employment Agency: The Effect of Social Capital on the Duration of Unemployment}

Philipp Marek, Benjamin Damm, Tong-Yaa Su 
This series presents research findings based either directly on data from the German SocioEconomic Panel study (SOEP) or using SOEP data as part of an internationally comparable data set (e.g. CNEF, ECHP, LIS, LWS, CHER/PACO). SOEP is a truly multidisciplinary household panel study covering a wide range of social and behavioral sciences: economics, sociology, psychology, survey methodology, econometrics and applied statistics, educational science, political science, public health, behavioral genetics, demography, geography, and sport science.

The decision to publish a submission in SOEPpapers is made by a board of editors chosen by the DIW Berlin to represent the wide range of disciplines covered by SOEP. There is no external referee process and papers are either accepted or rejected without revision. Papers appear in this series as works in progress and may also appear elsewhere. They often represent preliminary studies and are circulated to encourage discussion. Citation of such a paper should account for its provisional character. A revised version may be requested from the author directly.

Any opinions expressed in this series are those of the author(s) and not those of DIW Berlin. Research disseminated by DIW Berlin may include views on public policy issues, but the institute itself takes no institutional policy positions.

The SOEPpapers are available at

http://www.diw.de/soeppapers

\section{Editors:}

Jan Goebel (Spatial Economics)

Martin Kroh (Political Science, Survey Methodology)

Carsten Schröder (Public Economics)

Jürgen Schupp (Sociology)

Conchita D'Ambrosio (Public Economics)

Denis Gerstorf (Psychology, DIW Research Director)

Elke Holst (Gender Studies, DIW Research Director)

Frauke Kreuter (Survey Methodology, DIW Research Fellow)

Frieder R. Lang (Psychology, DIW Research Fellow)

Jörg-Peter Schräpler (Survey Methodology, DIW Research Fellow)

Thomas Siedler (Empirical Economics)

C. Katharina Spieß (Education and Family Economics)

Gert G. Wagner (Social Sciences)

ISSN: 1864-6689 (online)

German Socio-Economic Panel (SOEP)

DIW Berlin

Mohrenstrasse 58

10117 Berlin, Germany

Contact: Uta Rahmann | soeppapers@diw.de

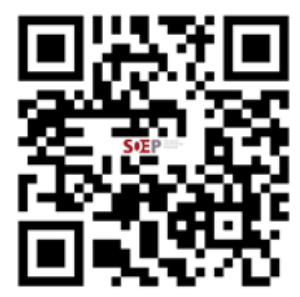




\title{
Beyond the Employment Agency:
}

\section{The Effect of Social Capital on the Duration of Unemployment}

\author{
Philipp Marek, Benjamin Damm, and Tong-Yaa Su ${ }^{*}$
}

\begin{abstract}
This paper relates an individual's social capital and the length of unemployment spells of the very same individual. For this purpose, we analyze several facets of an agent's social activities as determinants of her social capital. Social activities lead to social interactions within organizational settings, which build up social capital at the group level. Via social interactions an exchange of knowledge emerges, including information on opportunities to get a job. An econometric duration model based on German data is applied to empirically research the relationship between social capital and the duration of unemployment. Our results show that an individual's social capital positively affects an agent's probability to take up employment in the next time period. This implies social capital shortens the length of an unemployment spell significantly.
\end{abstract}

Keywords: Social Capital - Job Search - Duration Analysis

JEL Codes: Z13, J64, C41

\footnotetext{
* Marek: University of Bremen, Faculty of Business Studies and Economics, Hochschulring 4, 28359 Bremen, Germany and Halle Institute for Economic Research, Kleine Märkerstraße 8, 06108 Halle (Saale), Germany (e-mail: philipp.marek@uni-bremen.de); Damm: IHK24, Chamber of Commerce and Industry, Adolphsplatz 1, 20457 Hamburg, Germany (e-mail: damm@ihk24.de); Su (corresponding author): University of Bremen, Faculty of Business Studies and Economics, Hochschulring 4, 28359 Bremen, Germany (email: tong-yaa.su@uni-bremen.de).
} 


\section{Introduction}

Social capital and economic results as outcomes of this kind of capital have been investigated for some decades. In a cross-country analysis, Knack and Keefer (1997) conclude that social capital has concrete economic payoffs by examining 29 market economies, including poor and rich countries. Their analysis considers several social capital indicators, such as memberships in formal groups, and indicators for economic payoffs, such as investment per GDP. Fukuyama (1995) also identifies different social capital levels between different countries in the global economy. Conventional maps of the global economy divide the major players -a number of countries- into three groups: North America Free Trade Agreement, European Union, and East Asia. Deviating from these three clusters, the author suggests a new clustering. Fukuyama specifically contrasts countries "with healthy endowments of social capital” to countries with less social capital. Similarly, other authors demonstrate the relationship between social capital and economic development (e.g., Woolcook, 1998; Francois and Zabojnik, 2005), as well as social capital and economic performance (e.g., Solow, 2000; Westlund and Adam, 2010). Moreover, further studies are concerned with the relation between social capital and growth (e.g., Helliwell and Putnam, 1995; Yli-Renko et al., 2002; Routledge and von Amsberg, 2003; Iyer et al., 2005), income (e.g., Narayan and Pritchett, 1999; Yamamura, 2010), and also financial issues (e.g., Gomez and Santor, 2001; Guiso et al., 2004). Only few contributions, however, scrutinize the effect of social capital on unemployment (for one approach see Freitag and Kirchner, 2011), although Granovetter (1973) already emphasized the strength of strong and weak ties as to finding a new job. Strong and weak ties refer to personal contacts within social environments which may help to get out of unemployment.

This paper addresses this gap. Our contribution is twofold: (i) we analyze some dimensions of social activities at the level of an individual that can be considered as determinants of social capital. Assuming social activities at the individual level leads to social interactions, social capital at the group level builds up. Via social interactions an exchange of knowledge is possible, involving information on job opportunities for unemployed individuals. (ii) our empirical analysis based on German data shows that an individual's social capital significantly affects her economic outcomes, in this case the length of an unemployment spell of this individual. Via building up social capital at the group level, an individual's engagement in various dimensions of social activities increases an agent's probability to end a spell of unemployment. Apart from this 
effect in the entire sample, we find some significant and interesting special effects for subsamples with different types of individuals. For example, while voluntary services as one dimension of social activity raise the chance of shorter job search durations in the case of better-educated individuals, the religious involvement of foreigners significantly lowers their probability to get out of unemployment. ${ }^{1}$

This paper is organized as follows. In Section 2, we introduce some conceptual thoughts on potential determinants of social capital. Section 3 then describes the data used for testing our hypotheses as to the relationship between social capital and the length of unemployment spells. Section 4 presents an econometric model that draws on the estimation approach suggested by Cox (1972). Section 5 discusses our empirical results. Finally, Section 6 concludes.

\section{Determinants of social capital at the level of an individual and its economic outcome}

Our aim is to understand the influence of an individual's social capital on a concrete economic outcome of the very same individual. For this purpose, an individual's social capital is approximately measured by six dimensions of social activities this individual engages in and that leads to the build-up of social capital in groups or organizations, since social activities give rise to social interactions. An individual's economic outcome is measured by the duration of a spell of unemployment this individual experiences. We hypothesize that social activities at the level of an individual create social capital at the group level, which then affects the unemployment duration of an individual due to exchange of knowledge, including information as to jobs opportunities, through social interactions.

Two different perspectives on social capital are considered in the literature. First, there are findings on the determinants of social capital at the level of an individual (e.g. Glaeser et al., 2002; Verhaeghe and Tampubolon, 2012). This type of social capital is rooted in social characteristics of the person in question. These social characteristics underlie an individual's willingness to engage in social activities. In this context, especially the socialization within the

\footnotetext{
${ }^{1}$ Better-educated individuals have at least one of the following qualifications: high-school degree, professional apprenticeship, extended vocational training, college degree, or university degree. Foreigners do not have a German identification card.
} 
family and by peers and friends forms an individual's “social character”. Second, several scholars capture social capital at the group level. It is argued that the degree of social interactions explains the quality of group-level social capital. In accord with Putnam (1995), social capital refers to features of social organizations that facilitate coordination and cooperation for mutual benefits. Bloch et al. (2007) state social capital “can promote cooperation among groups.” Furthermore, Coleman (1988, 1990) as well as Nehapiet and Ghoshal (1998) distinguishes social capital, emerging through interactions among individuals in a group context, from capital that based on skills and knowledge which is embodied by persons at the individual level. Social capital, therefore, describes settings in which an individual can draw on her membership in a group to secure certain benefits (see Sobel, 2002). Consequently, since the conceptual notion of social capital comprises an individual and a group perspective, our approach includes the interplay between these two levels.

Our determinants of social capital depend on social activities carried out at the individual level. Disciplines such as social psychology or anthropology show that human beings possess a strong intrinsic inclination to socialize with other individuals (e.g., Ryan and Deci, 2000; Henrich, 2006), a type of behavior that is not exclusively driven by extrinsic, possibly pecuniary, incentives.

Figure 1 shows the determinants of social capital at the individual level that will enter our empirical analysis below. We include six dimensions of social activities, an individual may engage in, that build up social capital at the group level, i.e. social interactions. Moreover, these six dimensions are distinguished into two classifications. First, there are social activities that comprise friends and relatives in close social proximity to the individual in question. The first classification indicates internal social capital and consists of two determinants for social capital: meeting friends or relatives and helping friends or relatives. For instance, Oh et al. (2004) focus on friendship and socializing ties that matter in the context of internal social capital. And Stablein (2011) examines the important role of helping friends regarding this kind of capital. Second, the other classification of social activities include contacts in a broader, more public, group context that reach beyond the network of close friends and family members. This classification indicates external social capital and contains four determinants: political engagement captures the willingness to contribute to formal institutional systems and to take on responsibility for society as a whole. Fox (1996) as well as la due Lake and Huckfeldt (1998) identify links between 
political engagement and external social capital. Voluntary services include being active in volunteer organizations. Wollebaek and Selle (2002) found that activities in volunteer organizations foster the build-up of external social capital. Furthermore, religious involvement includes an individual's social activity as a member of a religious organization. Accordingly, Greeley (1997) stated that religious structures are a source of external social capital (also Fan, 2008). Finally, the social activity doing sports implies in many cases that an individual socially interacts with others and can lead, therefore, to the creation of external social capital at the group level. The formation of social capital via sport activities has been shown empirically (e.g., Seippel, 2006; Tonts, 2005).

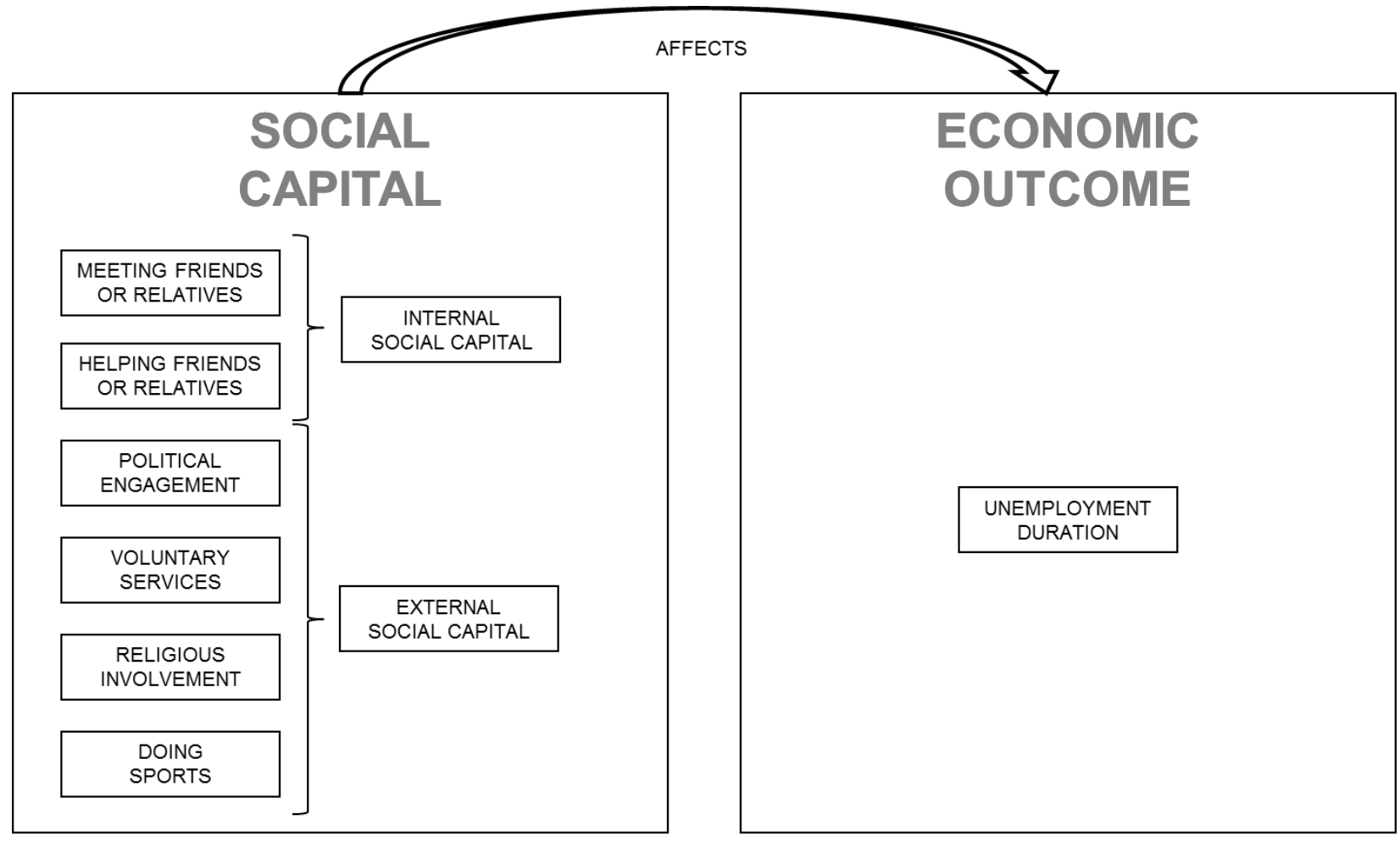

Figure 1: Determinants of social capital at the individual level and one economic outcome.

We suggest these six dimensions of an individual's social activities to be potential determinants for internal and external social capital at the group level. Social capital at the group level fosters the exchange of knowledge and experience among group members via social interactions (Davidsson and Honig, 2003), most probably including information on employment opportunities (Granovetter, 1973). As a consequence, we predict relatively shorter unemployment 
spells for agents that can tap a relatively high level of social capital at the level of a group. They exploit the high degree of knowledge exchange. We, thus, suggest two hypotheses capturing these relations:

Hypothesis 1:

Internal social capital shortens the length of an individual's unemployment spell by increasing the probability that this individual takes up employment in the next time step.

Hypothesis 2:

External social capital shortens the length of an individual's unemployment spell by increasing the probability that this individual takes up employment in the next time step.

\section{Data}

This paper reveals the case of Germany. We take data from the German Socio-Economic Panel $(\mathrm{SOEP})^{2}$, in order to verify our approach from the previous section. SOEP was established in 1984 by the German Institute for Economic Research (DIW). ${ }^{3}$ Furthermore, SOEP is a representative and longitudinal household survey which is conducted at an annual basis, gathering one wave per year. Each wave has observations from the previous calendar year. In our analysis, we restrict our sample to the survey information from the waves 1992 to $2013 .{ }^{4}$ The SOEP consists of more than 10.000 households and 20.000 adult persons living in Germany, including people with migration background. A wide range of different topics are included in the survey, such as health, earnings, and psychology. As a consequence, SOEP data are frequently taken in science and policy consultancy. Summary statistics on the variables extracted from the SOEP are in Table 1.

In this paper, we test the effect on unemployment duration. Moreover, we have six independent variables reflecting social capital and nine control variables. Uysal and Pohlmeier (2011) also use SOEP. The authors carry out an analysis which focuses on effects of the "Big Five” personality traits. Our duration data and control variables are obtained in a similar way

\footnotetext{
${ }^{2}$ Socio-Economic Panel (SOEP), data for years 1984-2013, version 30, SOEP, 2014, doi:10.5684/soep.v30

${ }^{3}$ See Wagner, Frick and Schupp (2007).

${ }^{4}$ Due to access limitations we use data from 1992-2013, that means we use observations which relate to 1991-2012. SOEP observations before 1991 refer mainly to one part of Germany, West Germany. So, observations before 1991 are not employed in our analysis.
} 
with the help of SOEP observations. More facts about our sample are provided in the rest of Section 3.

Table 1: Summary statistics on the extracted data. Source: SOEP, 1992-2013, own calculations.

\begin{tabular}{|c|c|c|c|c|c|c|}
\hline & Mean & $\begin{array}{l}\text { Standard } \\
\text { deviation }\end{array}$ & Median & Min. & Max. & Obs. \\
\hline Unemployment duration & 11.08 & 16.12 & 6 & 1 & 196 & 15,288 \\
\hline Meeting friends or relatives & 3.19 & 0.83 & 3 & 1 & 4 & 15,288 \\
\hline Helping friends or relatives & 2.55 & 0.80 & 2 & 1 & 4 & 15,288 \\
\hline Political engagement & 0.86 & 0.59 & 1 & 0 & 4 & 15,288 \\
\hline Voluntary services & 1.14 & 0.94 & 1 & 0 & 4 & 15,288 \\
\hline Religious involvement & 1.22 & 0.91 & 1 & 0 & 4 & 15,288 \\
\hline Doing sports & 1.85 & 1.26 & 1 & 0 & 4 & 15,288 \\
\hline German & 0.90 & 0.30 & 1 & 0 & 1 & 15,288 \\
\hline Female & 0.49 & 0.50 & 0 & 0 & 1 & 15,288 \\
\hline Education & 1.14 & 0.86 & 1 & 0 & 3 & 15,288 \\
\hline Children & 0.68 & 0.95 & 0 & 0 & 9 & 15,288 \\
\hline Age & 35.05 & 10.35 & 34 & 20 & 55 & 15,288 \\
\hline Married & 0.52 & 0.50 & 1 & 0 & 1 & 15,288 \\
\hline Self-employed & 0.02 & 0.14 & 0 & 0 & 1 & 15,288 \\
\hline City-state & 0.07 & 0.25 & 0 & 0 & 1 & 15,288 \\
\hline East & 0.42 & 0.49 & 0 & 0 & 1 & 15,288 \\
\hline
\end{tabular}

Note: Our assignments and definitions of the variables are in Table A1 (see Appendix).

\subsection{Dependent variable}

Social capital affects unemployment duration which is the dependent variable ${ }^{5}$ and measured by individual unemployment spells. Individuals are assumed to be unemployed if they are without a job and searching a new workplace at the same time. These individuals are registered at the employment agency. Each SOEP wave contains monthly information on the individuals' employment history in the previous year. Using this information, it is possible to calculate the unemployment spells. Unfortunately, some unemployment durations are censored. There are leftcensored spells (start of unemployment is before the individuals' first participation in the panel and therefore unknown) and right-censored ones (end of unemployment is after 2012 and therefore unknown). Some respondents have multiple unemployment durations if an employment spell is between two spells. On top of this, some individuals have a gap between the end month of an unemployment spell and start month of the following employment spell. In this case, unemployment spells are extended if the gap is not more than two months. The extension equals

\footnotetext{
${ }^{5}$ Precisely, the dependent variable is the hazard rate of the unemployment duration. For the sake of simplicity, we avoid the term "hazard rate" in this section. Section 4 gives detailed information on these hazard rates.
} 
to the amount of months where the respondents are neither unemployed nor employed, i.e. one or two months.

In order to reduce the potential biases driven by school enrollments, and early retirements, we focus our analysis on individuals between 20 and 55. Individuals, who did not report information on the explanatory variables, were excluded from the sample. Left-censored spells were excluded as well, since the starting month of these unemployment spells is unknown. As we will show below in Section 4, it is possible to account for right-censored data. In the end, we have 15,288 unemployment spells of 7,975 respondents, whereby 328 spells are right-censored.

\subsection{Independent variables}

The six dimensions meeting friends or relatives, helping friends or relatives, political engagement, voluntary services, religious involvement, and doing sports determines social capital. In Section 2, our approach was devised, reflecting these six dimensions as social activities (individual social capital) which, in turn, are driving forces for social interactions (group social capital). The willingness to be engaged in social activities is something individuals possess and this is assumed to be fairly independent of time. Thus, the six driving forces can be taken as independent variables for the estimation model in Section 4.

Some SOEP waves do not include information on above-mentioned activities. With exception of political engagement, Kunze and Suppa (2014) tabulate in which years SOEP obtained our social capital indicators. Political engagement, however, are obtained in the same years as the other five dimensions. Respondents were asked to choose one intensity of their activity on a scale with five opportunities. For example, the individuals faced the question, how often they go in for sports. Some of the answers are never or every day. All possible answers from the data (first line) according to the six social capital dimensions (first column) are in Table 2. 
Table 2: Determinants of social capital and five different intensities. Source: SOEP, 1992-2013, own calculations.

\begin{tabular}{|c|c|c|c|c|c|}
\hline & Never & Rather seldom & $\begin{array}{l}\text { Once a month } \\
\text { or more often }\end{array}$ & $\begin{array}{l}\text { Once a week } \\
\text { or more often }\end{array}$ & Every day \\
\hline Meeting friends or relatives & 0 & 336 & 3,041 & 5,264 & 6,647 \\
\hline Helping friends or relatives & 0 & 1,017 & 6,839 & 5,428 & 2,004 \\
\hline Political engagement & 3,415 & 10,931 & 690 & 159 & 93 \\
\hline Voluntary services & 3,001 & 9,343 & 1,455 & 836 & 653 \\
\hline Religious involvement & 2,520 & 8,855 & 2,583 & 750 & 580 \\
\hline Doing Sports & 1,384 & 6,546 & 2,974 & 1,641 & 2,743 \\
\hline
\end{tabular}

Note: Respondents were able to select only one out of these five intensities.

Now, we convert the five realizations of the six dimensions, in order to better get a first overview of the social capital indicators. We want to have six different participation dummies capturing whether the individuals are actively involved in social interactions. Assuming at least once a month to be one as well as never and rather seldom to be zero, we have one dummy variable for each of the six types for social capital. As a result, pro-active (dummy equals to one) and non-active participations (dummy equals to zero) are discerned. In Figure 2 is a map with aggregated activities of the pro-active participations per capita $x$ across Germany, depicting social capital. Figure 2 shows a high participation density in the north and south of Germany, while in the eastmost of Germany are the lowest participation density levels. High participation densities imply high per-capita shares of individuals’ activities, such as meeting or doing sports. 


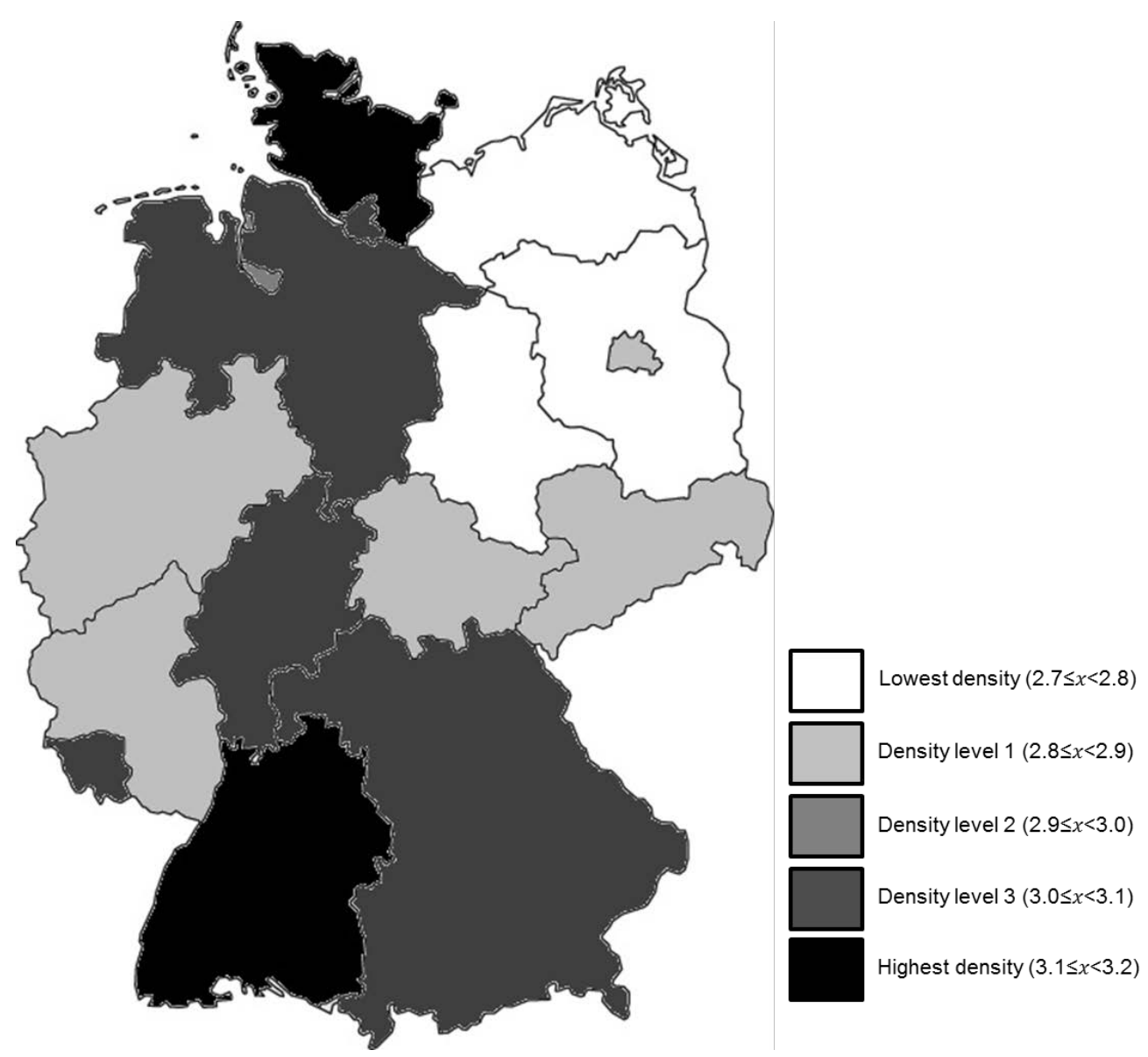

Figure 2: Participation densities $\boldsymbol{x}$ across Germany. Source: SOEP, 1992-2013, own calculations.

Notes: The calculation is done over all of the six participation types. We have information, which federal state the individual and her social participation can be assigned to. In order to get per-capita values, the total amount of proactive participations is divided by the overall observations of the according federal state.

\subsection{Control variables}

Assuming other characteristics to have an effect on unemployment duration, further independent variables are taken into account. We have socio-economic, demographic and geographic control variables in our empirical analysis, such as education, age, and city-state residence. Thus, the proper effect on economic outcome measures caused by social capital determinants can be better extracted.

For instance, we expect people with higher degrees to have a higher probability to be faster out of unemployment. Furthermore, older persons have more difficulties to find a new job generally, in comparison to younger ones. Since in the city-states Berlin, Hamburg, and Bremen 
are higher unemployment rates on average than in area states, it ought to be important to implement the property of a respondent, whether that person is living in a city-state or not. ${ }^{6}$

\section{Estimation approach}

We use a well-established estimation approach for duration data. This approach is proposed by Cox (1972) and it is appropriate to apply our SOEP data elucidated in Section 3. The remainder of Section 4 demonstrates, how we formally proceed to get our paper's research results. This is done within two steps. Firstly, we have some basic assumptions. Secondly, the Cox regression is introduced.

\subsection{Formal assumptions}

The following formal assumptions originate from some general ideas that rest on probability theory (e.g., Yang, 2007; Cramér, 1999; Bickel, 2015). Let us suppose individual unemployment duration to be a random variable $T$. Consequently, $t \in \mathbb{R}_{>0}$ are the realizations or observed values of the individual unemployment duration $T . \mathbb{R}_{>0}$ is the set of positive real numbers. It is possible to assume our data to be approximately continuous, since we have a high amount of different monthly durations (see also Section 4.2). Some possible events are $T \leq t, T>t, T=t$, or $t_{1}<T<t_{2}$. Given individual unemployment duration $T$ follows a certain kind of (but unknown) random distribution, the distribution function $F(t)$ denotes the probability of event $T \leq t$,

$$
F(t)=\operatorname{Prob}(T \leq t)
$$

whereby $F: \mathbb{R}_{>0} \rightarrow[0 ; 1]$ with $t \mapsto F(t)$ and $\operatorname{Prob}(T \leq t) \epsilon[0 ; 1]$. Now, we attain the density function by means of Equation (1),

$$
f(t)=\frac{\mathrm{d} F(t)}{\mathrm{d} t}
$$

with $f: \mathbb{R}_{>0} \rightarrow[0 ; \infty[$ and $t \mapsto f(t)$. Equation (2) implies the relations

\footnotetext{
${ }^{6}$ Most people are looking for a job close to their residence.
} 
(2a)

$$
F(t)=\operatorname{Prob}(T \leq t)=\int_{0}^{t} f(x) d x
$$

as well as

$$
\int_{0}^{\infty} f(t) d t=1
$$

That is, the probability or observed proportions as to any event of unemployment duration can be calculated by considering the density function $f(t)$ (see (2a) and 2(b)).

Now, we can give the survival function $S(t)$ with $\mathbb{R}_{>0} \rightarrow[0 ; 1], t \mapsto S(t)$, and Equation (1). The survival function $S(t)$ indicates the probability that unemployment duration $T$ is bigger than or survives time $t$,

$$
S(t)=1-F(t)=1-\operatorname{Prob}(T \leq t)=\operatorname{Prob}(T>t) .
$$

With Equations (2) and (3) the hazard rate $h(t)$, where $\mathbb{R}_{>0} \rightarrow[0 ; \infty[$ and $t \mapsto h(t)$, can be obtained by

$$
h(t)=\frac{f(t)}{S(t)}
$$

This leads to

$$
h(t)=\lim _{\Delta t \rightarrow 0^{+}} \frac{\operatorname{Prob}(t \leq T<t+\Delta t \mid T>t)}{\Delta t}
$$

(e.g., Cox ,1972; Han and Hausman, 1990). So, hazard rate $h(t)$ denotes the probability that unemployment duration $T$ ends short time later at $t+\Delta t$, divided by very small and constant $\Delta t$, assuming $T>t$.

PROOF: How to obtain Equation (5) via $f(t) / S(t)$ ?

Equations (2), (2a), and 2(b) imply

$$
f(t)=\lim _{\Delta t \rightarrow 0^{+}} \frac{\operatorname{Prob}(t \leq T<t+\Delta t)}{\Delta t} .
$$

Given $\Delta t$ is a small increment of unemployment duration $t, t_{2}-t_{1}, \Delta t \cdot f(t)$ is the probability of event $t \leq T<t+\Delta t$. By deploying Bayes’ rules and the rules for condition probabilities, 


$$
\operatorname{Prob}(A \mid B)=\frac{\operatorname{Prob}(B \mid A) \cdot \operatorname{Prob}(A)}{\operatorname{Prob}(B)}
$$

leads on to the probability of event $A$ under condition of event $B$. Considering Equations (3), (4), (5a), (5b), and $\left(\lim \left[\Delta t \rightarrow 0^{+}\right](\operatorname{Prob}(T>t \mid t \leq T<t+\Delta t))\right)=1$,

$$
\begin{aligned}
h(t) & =\frac{f(t)}{S(t)}=f(t) \cdot \frac{1}{S(t)}=\lim _{\Delta t \rightarrow 0^{+}} \frac{\operatorname{Prob}(t \leq T<t+\Delta t)}{\Delta t} \cdot \frac{1}{\operatorname{Prob}(T>t)} \\
& =\lim _{\Delta t \rightarrow 0^{+}} \frac{\operatorname{Prob}(t \leq T<t+\Delta t) \cdot 1}{\Delta t \cdot \operatorname{Prob}(T>t)}=\lim _{\Delta t \rightarrow 0^{+}} \frac{\operatorname{Prob}(t \leq T<t+\Delta t) \cdot \operatorname{Prob}(T>t \mid t \leq T<t+\Delta t)}{\Delta t \cdot \operatorname{Prob}(T>t)} \\
& =\lim _{\Delta t \rightarrow 0^{+}} \frac{\operatorname{Prob}(t \leq T<t+\Delta t) \cdot \frac{\operatorname{Prob}(t \leq T<t+\Delta t \mid T>t) \cdot \operatorname{Prob}(T>t)}{\operatorname{Prob}(t \leq T<t+\Delta t)}}{\Delta t \cdot \operatorname{Prob}(T>t)} \\
& =\lim _{\Delta t \rightarrow 0^{+}} \frac{\operatorname{Prob}(t \leq T<t+\Delta t) \cdot \operatorname{Prob}(t \leq T<t+\Delta t \mid T>t) \cdot \operatorname{Prob}(T>t)}{\Delta t \cdot \operatorname{Prob}(T>t) \cdot \operatorname{Prob}(t \leq T<t+\Delta t)} \\
& =\lim _{\Delta t \rightarrow 0^{+}} \frac{\operatorname{Prob}(t \leq T<t+\Delta t \mid T>t)}{\Delta t}
\end{aligned}
$$

shows, how to obtain the hazard rate $h(t)$ via $f(t) / S(t)$ in Equation (5).

\subsection{Cox regression}

We utilize a semiparametric regression model by Cox (1972) based on proportional hazard rates. The continuous Cox model is widely used in several disciplines, including economics (Kiefer, 1988). It is used for estimating empirical results with discrete monthly duration data (Dynarski and Sheffrin, 1990). Moreover, the model is used for discrete annual duration data (Besedeš and Prusa, 2006). But estimation bias issues might occur with discrete annual durations, when deploying the continuous specification by Cox (Hess and Persson, 2012). If, however, monthly duration data are available for a great deal of years, the distribution of these data can be assumed to be approximately continuous. This assumes, in turn, the data to be approximately continuous.

Our framework, in Section 4.1, supposes that it is unknown which distribution the unemployment durations $t_{i}$ of observation $i=1,2, \ldots$ are stemming from. Appropriate candidates for the unknown random distribution might be the exponential distribution, the distribution models by Weibull (1939), and by Hjorth (1980). To know the distribution means to know the 
shape of the according hazard rate $h\left(t_{i}\right)$ and different probabilities as to unemployment durations $t_{i}$ depending on other impact factors, such as social capital determinants. There are two conspicuous advantages of the semiparametric Cox model with proportional hazard rates. Like in Section 4.1 and in the SOEP data, Cox (1972) proposes a model which incorporates unknown hazard rates and right-censored observations.

The first equation of Cox (1972) is Equation (5) from Section 4.1 and gives the hazard rate $h(t)$. With Cox regression the relationship

$$
h\left(t_{i} ; \mathbf{z}_{i}\right)=h_{b}\left(t_{i}\right) \cdot \exp \left(\mathbf{z}_{i}^{\prime} \cdot \boldsymbol{\beta}\right)
$$

is estimated, where $h\left(t_{i} ; \boldsymbol{z}_{i}\right)$ are unknown hazard rates depending on individual unemployment duration $t_{i}$ of observation $i=1,2, \ldots$ and regressors $\boldsymbol{z}_{i} . \mathbf{z}_{i}$ is a $n \times 1$ vector of social capital indicators and control variables (see Appendix, Table A1). $h_{b}\left(t_{i}\right)$ is the unknown baseline hazard rate. In accord with $\operatorname{Cox}(1972)$, if $\boldsymbol{z}_{i}^{\prime}=(0,0, \ldots, 0)$, i.e. there is no impact from "further measurements” outside, unknown hazard rates equal to unknown baseline hazards, $h\left(t_{i} ; z_{i}\right)=$ $h_{b}\left(t_{i}\right) .^{7} \mathbf{z}_{i}^{\prime}$ is a $1 \times n$ vector. $\boldsymbol{\beta}$ is a $n \times 1$ vector and are the coefficients of $\mathbf{z}_{i}^{\prime} \cdot h_{b}\left(t_{i}\right)$ is the nonparametric and $\exp \left(\mathbf{z}_{i}^{\prime} \cdot \boldsymbol{\beta}\right)$ is the parametric part in the semiparametric regression. The bigger $\exp \left(\mathbf{z}_{i}^{\prime} \cdot \boldsymbol{\beta}\right)$ is, the smaller is relatively the impact power of $h_{b}\left(t_{i}\right)$ on $h\left(t_{i} ; \mathbf{z}_{i}\right)$. That is the reason, why the term "proportional hazard rates” is used in these kinds of regressions.

With the help of Equations (5) and (6), we obtain

$$
\lim _{\Delta t_{i} \rightarrow 0^{+}} \frac{\operatorname{Prob}\left(t_{i} \leq T<t_{i}+\Delta t_{i} \mid T>t_{i}\right)}{\Delta t_{i}}\left(\mathbf{z}_{i}\right)=h_{b}\left(t_{i}\right) \cdot \exp \left(\mathbf{z}_{i}^{\prime} \cdot \boldsymbol{\beta}\right)
$$

Therefore, our empirical results in Section 5 can be interpreted as follows. If coefficients $\boldsymbol{\beta}$ for social capital and control variables are estimated with a significantly positive algebraic sign, then the hazard rate of unemployment durations $h\left(t_{i} ; \boldsymbol{z}_{i}\right)$ tends to increase with rising $\boldsymbol{z}_{i}$. The hazard rate $h\left(t_{i} ; z_{i}\right)$ denotes the probability of event $t_{i} \leq T<t_{i}+\Delta t_{i} \mid T>t_{i}$, divided by very small time increments $\Delta t_{i}$, depending on $\exp \left(\mathbf{z}_{i}^{\prime} \cdot \boldsymbol{\beta}\right)$. That means, given $\boldsymbol{z}_{i}$ is increasing, the probability that unemployment duration $T$ ends short time later at $t_{i}+\Delta t_{i}$ is tending to increase as well, assuming unemployment duration $T>t_{i}, \Delta t_{i}$ is (constantly) very small, as well as $\boldsymbol{\beta}$ is significantly and positively estimated (see Equation (7)). As a result, more social capital appears

\footnotetext{
${ }^{7} \exp (0)=1$, see Equation (6).
} 
to lead to a higher probability that unemployment duration ends in the next very small time step. This implies to have shorter unemployment and job search durations on average. Analogically, more social capital tend to lead to lower probabilities of getting out of unemployment short time later, if $\boldsymbol{\beta}$ is significantly estimated with a negative algebraic sign.

Finally, after some simplifications and according to Cox (1972), we account for the fact that there are unknown hazard rates and right-censored observations.

$$
\frac{\exp \left(\mathbf{z}_{i}^{\prime} \cdot \boldsymbol{\beta}\right)}{\sum_{l \in \Re\left(t_{i}\right)} \exp \left(\mathbf{z}_{l}^{\prime} \cdot \boldsymbol{\beta}\right)}
$$

gives the proportion (probability) of the impact from outside depending on observation $i$, where $l$ are non-censored and ordered observations that survived $t_{i}, l \in \Re\left(t_{i}\right)$. From here on, "[...] maximum-likelihood estimates of $\boldsymbol{\beta}$ can be obtained [...] in the usual way [.]” (Cox, 1972). That is, we get

$$
L(\boldsymbol{\beta})=\prod_{i=1}^{k}\left(\frac{\exp \left(\mathbf{z}_{i}^{\prime} \cdot \boldsymbol{\beta}\right)}{\sum_{l \in \Re\left(t_{i}\right)} \exp \left(\mathbf{z}_{l}^{\prime} \cdot \boldsymbol{\beta}\right)}\right)^{c_{i}}
$$

and

$$
\log (L(\boldsymbol{\beta}))=\sum_{i=1}^{k} c_{i} \cdot \mathbf{z}_{i}^{\prime} \cdot \boldsymbol{\beta}-\sum_{i=1}^{k} c_{i} \cdot\left(\log \left(\sum_{l \in \Re\left(t_{i}\right)} \exp \left(\mathbf{z}_{l}^{\prime} \cdot \boldsymbol{\beta}\right)\right)\right)
$$

for the likelihood $L(\boldsymbol{\beta})$ and $\log$-likelihood $\log (L(\boldsymbol{\beta}))$ function. Dummy $c_{i}=1$, if observation $i$ has a non-censored unemployment duration (end of duration is known), $c_{i}=0$ otherwise. For more details regarding maximum-likelihood estimates in semiparametric regressions with proportional hazard rates, it is possible to look into the literature (e.g., Hosmer et al., 2008; Kahn and Sempos, 1989; Kalbfleisch and Prentice, 2002). For example, we can find information on derivations of function $\log (L(\boldsymbol{\beta}))$, i.e. Score function and Hessian Matrix, in order to get maximum-likelihood estimates for $\boldsymbol{\beta}$. 


\section{Empirical results}

This section presents the empirical results based on the continuous Cox analysis described above. Our estimation outputs are in the Appendix. Table A1 shows our variable assignments and definitions. In the following, we first provide basic information for the Tables A2 and A3. After that, we give detailed explanations on our paper's research findings illustrated by the columns I to XVII in A2 and A3.

We report, in Table A2, the regression results for the entire sample of 15,288 unemployment spells. Each column focuses on a distinct specification of the measurement of social capital. As described earlier, social capital is represented by six dimensions: meeting friends or relatives, helping friends or relatives, political engagement, voluntary services, religious involvement, and doing sports. In order to test whether each measurement of social capital contributes to the explanatory power of the regression, we additionally perform a likelihood-ratio test (LR test). The LR test for joint significance is done between the unrestricted specifications, reported in column I to IX, and a restricted model, which includes solely the set of control variables. ${ }^{8}$

In a first step, we transform the self-evaluated information on the six social capital dimensions into six different participation dummy variables in total, capturing whether an individual is actively involved in social interactions. What does "actively" mean? The dummy variable takes on the value of one, if an individual reports a frequency of at least once a month in the corresponding social capital dimension. If an individual is never or rather seldomly involved in one dimension, the corresponding participation dummy variable takes on the value of zero. This holds true for each of the six dummies. Column I contains the estimates of the most aggregate social capital measurement, which is solely split into two classifications: one dummy for internal (meeting and helping friends or relatives) as well as one dummy for external (political engagement, voluntary services, religious involvement, and doing sports) social capital. ${ }^{9}$ Internal social capital equals to one, if at least one out of the corresponding two participation dummies equals to one. External social capital equals to one, if at least one out of the corresponding four

\footnotetext{
${ }^{8}$ The regression results of the restricted specification without social capital indicators are not reported in this paper. But it can be made available upon request.

${ }^{9}$ We decided to omit a transformation with merely one dummy for all social capital determinants, since only $0.3 \%$ of the respondents reported the two lowest categories (never and rather seldom) for each of the six dimensions at the same time. So, the dummy, referring to all of the six social capital dimensions, equals to one in $99.7 \%$ of cases.
} 
participation dummies equals to one. In column II, we report a regression outcome of a specification, which is "less aggregated," with the six social capital participation dummies.

In a second step, we consider more detailed information of the social involvement by creating four dummy variables indicating four distinct intensities or categories (rather seldom, once a month, once a week, and every day). These four categories relate to each of the six social capital dimensions. This procedure enables us to investigate whether the intensity of social activities has an impact on the probability to find a job. Instead of including a count variable, which would assume a linear relation of the social capital intensities, we include a dummy variable for each category with never being defined as the baseline category. Hence, the corresponding coefficients of the four categories may be interpreted as how the intensity of social involvement influences the hazard rate ${ }^{10}$ with respect to the baseline category. Column III contains the regression output for the specification including category dummies for all social capital indicators. The results reported in columns IV to IX are based on a specification including category dummies of only one out of six social capital indicators. For each regression, comprising category dummies, we perform a LR test whether the intensity of social activities has an impact on the probability to get out of unemployment. Therefore, we compare the log-likelihood values of the unrestricted specifications, reported in columns III to IX, with the log-likelihood values of the restricted specifications, including participation dummy variables whether an individual is actively (once $a$ month, once a week, or every day) involved in the corresponding social capital dimension instead of the category dummies. As an illustration, in column III we compare the unrestricted specification, containing category dummies for the six dimensions of social capital, with the restricted specification in column II, containing six participation dummy variables indicating whether an individual is actively engaged in the corresponding social capital dimension. LR tests, in columns IV to IX, refer to a specification with the participation dummy of only one social capital indicator. $^{11}$

Table A3 illustrates whether the impact of social capital and of control variables differs across subsamples. The four types of subsamples are citizenship, gender, educational background, and number of children living in the household. For each dimension of social capital, we include the

\footnotetext{
${ }^{10}$ We gave concrete information about hazard rates in Section 4 (see Equations (4), (5), and (6)). Moreover, there are hints on how to interpret these rates and our empirical results (see Equation (7)).

${ }^{11}$ The regression results of these restricted specifications are not reported in this paper. But it can be made available upon request.
} 
participation dummy variable capturing whether an individual is regularly involved in the corresponding activity at least once a month. Firstly, the sample is split into subsamples with respect to the citizenship of the individuals. Column $\mathrm{X}$ contains the estimates of the subsample of German citizens, while the regression output of the subsample including individuals with a foreign citizenship is reported in column XI. Secondly, we report the results for the subsample of women in column XII, and of male individuals in column XIII. Thirdly, in column XIV and XV, the sample is separated by the educational background with individuals who have at least a high school degree or passed a professional apprenticeship (XV) and with individuals who have not achieved one out of these qualifications yet (XIV). Fourthly, columns XVI and XVII split the sample into a subsample of childless individuals as well as into a subsample with individuals that, by contrast, have one child or more children.

Henceforth, let us absorb the detailed facts of our paper's research findings. In column I of Table A2, we show that the most aggregate measures of social activities, internal and external social capital, lead to a significant increase in the hazard rate and thereby to an increase in the probability to find a job. A more detailed investigation in column II suggests that the positive impact of internal social capital is driven by meeting and helping friends or relatives, whereas the positive effect of external social capital may be explained by voluntary services, partly by religious involvement, and strongly by doing sports. The impact of political engagement on the probability to find a job appears to be negligible and insignificant. When testing the joint significance of the social capital dummies in column I and II by means of a LR test, we show that under both specifications social capital measurements clearly contribute to the explanatory power of the regressions. Beyond that, a LR test between the specifications in columns I and II reports chi-squared statistics of 39.79 with 4 degrees of freedom and a corresponding p-value of $0.000{ }^{12}$ Thus, a detailed investigation of internal and external social capital provides additional insights.

While the specifications in columns I and II merely capture the active participation in social activities, the regression output in columns III to IX focuses on the impact of the intensity of social activities on the hazard rate of unemployment durations. That means the impact of social capital on the probability of escaping from unemployment. In column III, we include the category dummies for each social capital indicator. As suggested by chi-squared statistics of 53.49 with 16

${ }^{12}$ These statistics are not in Table A2. 
degrees of freedom and a corresponding p-value of 0.000 , the intensity of social activities appears to matter when investigating the probability to get out of unemployment. The coefficient estimates in column III suggest that predominantly the intensity of meeting as well as doing sports raises the probability to find a job. The intensity of helping and voluntary services also lead to an increase in the hazard rates, whereas religious involvement and political engagement tend to provide little or even no effect on these rates.

The specifications in columns IV to IX are focusing on the intensity of each social capital dimension separately. Column IV contains three category dummies for meeting. Since none of the respondents reported that she never meets friends or relatives, the coefficients are interpreted with respect to the baseline category of rather seldom. The same holds true for the indicator helping. For meeting, all coefficient estimates are significantly positive with a very similar magnitude. While the LR test for joint significance reports a significant impact of these variables on the model, the LR test investigating the impact of the intensity reports chi-squared statistics of 3.82 with 2 degrees of freedom, corresponding to a p-value of 0.149 . These results suggest that meeting friends or relatives has a beneficial impact in the job search, albeit a higher frequency does not compellingly translate into a higher probability to get out of unemployment. For the dimension capturing the answers on helping, the regression in column $\mathrm{V}$ shows significantly positive estimates for all categories. The magnitude of the positive effect apparently decreases with a higher frequency. The joint significant impact of these dummy variables is confirmed by the LR test. Moreover, the LR test on relevance of the intensity reports a chi-squared value of 7.98 with 2 degrees of freedom and a p-value of 0.018 . This test suggests that the intensity of helping matters, when investigating the hazard rate of unemployment duration. As a result, the lower coefficients observed for higher frequencies suggest that people, who help their friends or relatives on daily a basis, are less likely to get out of unemployment than individuals helping at a lower frequency. A potential explanation could be that individuals, who are too much engaged in assisting people in their close environment, may not be able to dedicate enough time to the job search.

In column VI, all coefficient estimates for the category dummy variables capturing the extent of political engagement are insignificant. The LR tests for joint significance and for the impact of the intensity indicate that neither participations in political groups nor the intensity influences the probability to find an employment. 
The analysis as to the impact of voluntary services and religious involvement in columns VII and VIII provides similar findings. For both specifications, we observe a negligible impact for the category of rather seldom, whereas a frequency of once a month and once a week is significantly positive for both social capital indicators. In comparison to the baseline category never, the impact of a daily engagement in the corresponding activity does not appear to have an influence on the hazard rate. For voluntary services and religious involvement, the LR tests for joint significance confirm the explanatory power and positive impact of active participation in the corresponding dimensions. Although the coefficient estimates of the categories, capturing frequencies of at least once a month, tend to differ, the LR test on the impact of the intensity does not reject the hypothesis that these three coefficients are equal. Hence, active participations in voluntary services or in religious groups raise the probability to find a job, whereas a higher frequency in these activities does not compulsorily lead on to an increase in the hazard rates.

The final social capital dimension, doing sports, is reported in column IX. The coefficient estimates are increasing in the frequencies of sportive activities. The LR tests on joint significance and on the intensity confirm that the category dummies have a significant impact and this impact depends on its frequency. Simply put, individuals who are more frequently engaged in sports are more likely to find an employment.

All coefficient estimates of the control variables are highly significant and only vary slightly across the specifications in Table A2. Given the estimation output, individuals with a German citizenship, married, and self-employed individuals have a higher probability to find a job, while women face more difficulties in getting out of unemployment. With respect to the baseline category of the lowest educational degree, a higher educational background raises the chances of individuals to find a job. Concerning the impact of children in a household, the estimates illustrate a negative relation between the amount of children and the probability to find a job. Consequently, the more children a person has, the lower is the probability to escape from unemployment. We have uniformly negative coefficient estimates for individual's age that suggest older individuals are exposed to a lower probability to find an employment. The place of residency also tends to influence the hazard rate. Firstly, individuals living in one out of the three city states face more difficulties in the search for an employment. Secondly, the likelihood to get out of unemployment is significantly smaller, for residents of federal states that can be assigned to the federal states of former East Germany. 
Finally, we give more detailed explanations on Table A3. The regression results listed in this table provide information whether the impact of social capital differs between specific groups of the sample. When distinguishing between German and foreign individuals, we find an active engagement of Germans in five out of the six social capital dimensions raises the probability to find a job. Just active participations in political groups have no impact on both subsamples. In contrast to the German subsample, the impact of social capital to find an employment is less pronounced for foreigners. One reason is: the sample size of the subsample with Germans is approximately ten times larger, which leads to higher variance estimates for the foreigner subsample. For foreign individuals, doing sports also appears to facilitate the search for job, whereas the effect of religious involvement is negative on the hazard rate. For the German subsample, the impact of the other control variables is similar to the ones of the entire sample. For the foreigners' subsample only the age, marital, and self-employment status are significant and qualitatively in line with the previous estimates. The effect of the educational background only partly explains the hazard rate, while gender, amount of children, and the place of residency do not tend to affect the probability of foreign individuals to find a job.

The distinction between females and males in column XII and XIII shows the differences regarding the determinants of the hazard rate are less pronounced in comparison to the distinction driven by citizenship. Concerning the social capital indicators, meeting and doing sports are the dominating social capital dimensions explaining the hazard rate of both subsamples. A slight difference can be observed for religious involvement. While the impact is insignificant for women, the probability for men to find an employment significantly rises with religious activities. The effect of the control variables for the subsample of women is in line with the output obtained from the entire sample. Considering the control variables in the subsample with males, we observe that impact of the amount of children on the hazard rate turns to be significantly negative, if a man has 3 or more children. The residency in East Germany has no effect on the probability to find a job for men.

With respect to the educational background, the results in columns XIV and XV show that social capital is much less important for job search of low-skilled individuals. Doing sports is the only social capital indicator reporting an impact on the hazard rate, which is positive and even more pronounced than the estimation obtained for the subsample of better-educated individuals. As for the subsample of German individuals, we observe, regarding better-educated individuals, 
significantly positive estimates for five social capital indicators and political engagement as the only social capital measure with an insignificant impact on the probability to find a job. The impact of the control variables on the hazard rates differs only slightly between less-educated and better-educated individuals. Thereby, it is worth pointing out that for unskilled individuals the citizenship ostensibly does not matter in the job search.

For the subsamples distinguishing whether children are living in the individuals' household, columns XVI and XVII report clear differences as to the effect of social capital between both subsamples. For childless individuals, meeting and doing sports are the most important informal channels in the search for a job. The former dimension does not tend to matter for individuals with children. For this subsample, activities in helping, voluntary services, religious involvement, and doing sports raise the probability to find a job. Furthermore, we observe only minor differences in the effect of the control variables between childless and people with children.

\section{Conclusions}

Our findings suggest that social capital plays a major role in determining an individual's spell length of unemployment. Hence, individuals may indeed benefit from the build-up of social capital at the group level - an effect that lies beyond the services of an employment agency.

The approach to social capital proposed in this paper offers an "individual-group-individual" concept. Our goal is to examine the consequences of an individual's social capital on group social capital that, in turn, affects an individual's economic outcomes. An individual's social capital can be determined by a person's engagement in social activities, i.e. meeting friends or relatives, helping friends or relatives, political engagement, voluntary services, religious involvement, and doing sports. Within certain organizational settings or group contexts, social activities leads to social interactions among individuals and that give rise to social capital at the group level. The latter comprises knowledge and experience exchange between group members that can include valuable information about employment opportunities for individuals. As a consequence, we hypothesized social capital to lead to higher probabilities of terminating an individual's spell of unemployment. 
Our empirical investigation focused on six dimensions of social activities an individual might engage in that build up social capital at the group level. The six social capital determinants were then related to the length of an individual's spell of unemployment. The econometric results reveal meeting friends or relatives significantly shortens an agent's job search, whereas a higher intensity of engagement in this social activity does not imperatively translate into a higher probability to get out of unemployment. Moreover, helping friends or relatives does not only have an impact on individuals' unemployment durations, but also the intensity of this activity matters when investigating the according probabilities to end an unemployment spell. Lower coefficients observed for higher activity intensities suggest that individuals who help their friends or relatives on a daily basis, are less likely to get out of unemployment than individuals helping other people at a lower intensity. Unlike the first two dimensions of social capital, neither the participation of an individual in political engagement nor its intensity influences the probability to find an employment. However, a regular participation in voluntary services or in religious involvement raises the probability to find a job, whereas a higher intensity in these two dimensions does not lead to an increase as to the probability of getting out of unemployment. Finally, individuals who are more frequently engaged in doing sports are more likely to more rapidly take up employment again.

We solely investigate one special case in this paper: social activities and unemployment durations of individuals in Germany. It will be of outstanding interest to examine other social capital dimensions (e.g., individual's trust levels), other individual economic outcome measures (e.g., income), or other contexts of analysis (e.g., an analysis as to other countries). 


\section{Appendix}

Table A1: Variables. Source: SOEP, 1992-2013, own assignments and definitions.

\begin{tabular}{|c|c|c|}
\hline & Assignments & Definitions \\
\hline Unemployment duration & UNE & Unemployment durations in months. \\
\hline \multirow[t]{6}{*}{ Meeting friends or relatives } & MEE_0 & Dummy equals to 1 if never. \\
\hline & MEE_1 & Dummy equals to 1 if rather seldom. \\
\hline & MEE_2 & Dummy equals to 1 if once a month or more often. \\
\hline & MEE_3 & Dummy equals to 1 if once a week or more often. \\
\hline & MEE_4 & Dummy equals to 1 if every day. \\
\hline & MEE_D & Dummy equals to 1 if at least once a month or more often. \\
\hline \multirow[t]{6}{*}{ Helping friends or relatives } & HEL_0 & Dummy equals to 1 if never. \\
\hline & HEL_1 & Dummy equals to 1 if rather seldom. \\
\hline & HEL_2 & Dummy equals to 1 if once a month or more often. \\
\hline & HEL_3 & Dummy equals to 1 if once a week or more often. \\
\hline & HEL_4 & Dummy equals to 1 if every day. \\
\hline & HEL_D & Dummy equals to 1 if at least once a month or more often. \\
\hline \multirow[t]{6}{*}{ Political engagement } & POL_0 & Dummy equals to 1 if never. \\
\hline & POL_1 & Dummy equals to 1 if rather seldom. \\
\hline & POL_2 & Dummy equals to 1 if once a month or more often. \\
\hline & POL_3 & Dummy equals to 1 if once a week or more often. \\
\hline & POL_4 & Dummy equals to 1 if every day. \\
\hline & POL_D & Dummy equals to 1 if at least once a month or more often. \\
\hline \multirow[t]{6}{*}{ Voluntary services } & VOL_0 & Dummy equals to 1 if never. \\
\hline & VOL_1 & Dummy equals to 1 if rather seldom. \\
\hline & VOL_2 & Dummy equals to 1 if once a month or more often. \\
\hline & VOL_3 & Dummy equals to 1 if once a week or more often. \\
\hline & VOL_4 & Dummy equals to 1 if every day. \\
\hline & VOL_D & Dummy equals to 1 if at least once a month or more often. \\
\hline \multirow[t]{6}{*}{ Religious involvement } & REL_0 & Dummy equals to 1 if never. \\
\hline & REL_1 & Dummy equals to 1 if rather seldom. \\
\hline & REL_2 & Dummy equals to 1 if once a month or more often. \\
\hline & REL_3 & Dummy equals to 1 if once a week or more often. \\
\hline & REL_4 & Dummy equals to 1 if every day. \\
\hline & REL_D & Dummy equals to 1 if at least once a month or more often. \\
\hline \multirow[t]{6}{*}{ Doing sports } & SPO_0 & Dummy equals to 1 if never. \\
\hline & SPO_1 & Dummy equals to 1 if rather seldom. \\
\hline & SPO_2 & Dummy equals to 1 if once a month or more often. \\
\hline & SPO_3 & Dummy equals to 1 if once a week or more often. \\
\hline & SPO_4 & Dummy equals to 1 if every day. \\
\hline & SPO_D & Dummy equals to 1 if at least once a month or more often. \\
\hline Internal social capital & INT & Dummy equals to 1 if MEE_D or HEL_D is 1 . \\
\hline External social capital & EXT & Dummy equals to 1 if POL_D, VOL_D, REL_D or SPO_D is 1 . \\
\hline German & GER & Dummy equals to 1 if German. \\
\hline Female & FEM & Dummy equals to 1 if female. \\
\hline \multirow[t]{4}{*}{ Education } & EDU_0 & Dummy equals to 1 if no degree or 10 years of school at most. \\
\hline & EDU_1 & Dummy equals to 1 if high school degree or professional apprenticeship. \\
\hline & EDU_2 & Dummy equals to 1 if high school degree and extended vocational training. \\
\hline & EDU_3 & Dummy equals to 1 if highest degree is college or university degree. \\
\hline \multirow[t]{4}{*}{ Children } & CHI_0 & Dummy equals to 1 if individual has no children. \\
\hline & CHI_1 & Dummy equals to 1 if individual has one child. \\
\hline & CHI_2 & Dummy equals to 1 if individual has two children. \\
\hline & CHI_3 & Dummy equals to 1 if individual has three children or more. \\
\hline Age & AGE & Age in years. \\
\hline Married & MAR & Dummy equals to 1 if married. \\
\hline Self-employed & SEL & Dummy equals to 1 if self-employed. \\
\hline City-state & CIT & Dummy equals to 1 if residence in a city-state. \\
\hline East & EAS & Dummy equals to 1 if residence in former East Germany. \\
\hline
\end{tabular}

Notes: Variables refer to individuals at the beginning of an unemployment spell. City-state is 1 if federal state is Berlin, Hamburg, or Bremen; 0 otherwise. 
Table A2: Estimation of coefficients for social capital and control variables with the entire sample.

\begin{tabular}{|c|c|c|c|c|c|c|c|c|c|}
\hline & I & II & III & IV & V & VI & VII & VIII & IX \\
\hline \multicolumn{10}{|l|}{ Social capital } \\
\hline INT & $\begin{array}{c}0.196 * * * \\
(0.076)\end{array}$ & & & & & & & & \\
\hline EXT & $\begin{array}{c}0.153^{* * *} \\
(0.018)\end{array}$ & & & & & & & & \\
\hline MEE_D & & $\begin{array}{c}0.205^{* * *} \\
(0.060)\end{array}$ & & & & & & & \\
\hline HEL_D & & $\begin{array}{c}0.077 * * \\
(0.035)\end{array}$ & & & & & & & \\
\hline POL_D & & $\begin{array}{l}-0.032 \\
(0.037)\end{array}$ & & & & & & & \\
\hline VOL_D & & $\begin{array}{c}0.050 * * \\
(0.023)\end{array}$ & & & & & & & \\
\hline REL_D & & $\begin{array}{l}0.038^{*} \\
(0.020)\end{array}$ & & & & & & & \\
\hline SPO_D & & $\begin{array}{c}0.146 * * * \\
(0.018)\end{array}$ & & & & & & & \\
\hline MEE_2 & & & $\begin{array}{c}0.204^{* * *} \\
(0.062)\end{array}$ & $\begin{array}{c}0.256^{* * * *} \\
(0.060)\end{array}$ & & & & & \\
\hline MEE_3 & & & $\begin{array}{c}0.228^{* * *} \\
(0.061)\end{array}$ & $\begin{array}{c}0.300 * * * \\
(0.059)\end{array}$ & & & & & \\
\hline MEE_4 & & & $\begin{array}{c}0.200^{* * *} \\
(0.061)\end{array}$ & $\begin{array}{c}0.275^{* * *} \\
(0.058)\end{array}$ & & & & & \\
\hline HEL_2 & & & $\begin{array}{c}0.094^{* * *} \\
(0.036)\end{array}$ & & $\begin{array}{c}0.162 * * * \\
(0.035)\end{array}$ & & & & \\
\hline HEL_3 & & & $\begin{array}{l}0.067^{*} \\
(0.037)\end{array}$ & & $\begin{array}{c}0.153 * * * \\
(0.035)\end{array}$ & & & & \\
\hline HEL_4 & & & $\begin{array}{c}0.014 \\
(0.042)\end{array}$ & & $\begin{array}{c}0.089 * * \\
(0.040)\end{array}$ & & & & \\
\hline POL_1 & & & $\begin{array}{l}-0.058 \\
(0.045)\end{array}$ & & & $\begin{array}{c}0.010 \\
(0.020)\end{array}$ & & & \\
\hline POL_2 & & & $\begin{array}{l}-0.105^{*} \\
(0.058)\end{array}$ & & & $\begin{array}{c}0.038 \\
(0.042)\end{array}$ & & & \\
\hline POL_3 & & & $\begin{array}{l}-0.005 \\
(0.091)\end{array}$ & & & $\begin{array}{c}0.108 \\
(0.082)\end{array}$ & & & \\
\hline POL_4 & & & $\begin{array}{c}0.031 \\
(0.114)\end{array}$ & & & $\begin{array}{c}0.136 \\
(0.106)\end{array}$ & & & \\
\hline VOL_1 & & & $\begin{array}{c}0.017 \\
(0.046)\end{array}$ & & & & $\begin{array}{c}0.013 \\
(0.021)\end{array}$ & & \\
\hline VOL_2 & & & $\begin{array}{l}0.099 * * \\
(0.050)\end{array}$ & & & & $\begin{array}{c}0.136 * * * \\
(0.032)\end{array}$ & & \\
\hline VOL_3 & & & $\begin{array}{c}0.069 \\
(0.052)\end{array}$ & & & & $\begin{array}{c}0.116^{* * * *} \\
(0.040)\end{array}$ & & \\
\hline VOL_4 & & & $\begin{array}{c}0.005 \\
(0.060)\end{array}$ & & & & $\begin{array}{c}0.049 \\
(0.044)\end{array}$ & & \\
\hline REL_1 & & & $\begin{array}{l}-0.037 \\
(0.036)\end{array}$ & & & & & $\begin{array}{l}-0.002 \\
(0.023)\end{array}$ & \\
\hline REL_2 & & & $\begin{array}{c}0.013 \\
(0.040)\end{array}$ & & & & & $\begin{array}{c}0.071^{* *} \\
(0.029)\end{array}$ & \\
\hline REL_3 & & & $\begin{array}{c}0.023 \\
(0.049)\end{array}$ & & & & & $\begin{array}{l}0.083^{*} \\
(0.043)\end{array}$ & \\
\hline REL_4 & & & $\begin{array}{l}-0.015 \\
(0.056)\end{array}$ & & & & & $\begin{array}{c}0.033 \\
(0.047)\end{array}$ & \\
\hline SPO_1 & & & $\begin{array}{c}0.135^{* * *} \\
(0.037)\end{array}$ & & & & & & $\begin{array}{c}0.086^{* * *} \\
(0.030)\end{array}$ \\
\hline SPO_2 & & & $\begin{array}{c}0.208^{* * *} \\
(0.040)\end{array}$ & & & & & & $\begin{array}{c}0.177^{* * * *} \\
(0.033)\end{array}$ \\
\hline SPO_3 & & & $\begin{array}{c}0.281^{* * *} \\
(0.040)\end{array}$ & & & & & & $\begin{array}{c}0.273^{* * *} \\
(0.037)\end{array}$ \\
\hline SPO_4 & & & $\begin{array}{c}0.322 * * * \\
(0.041)\end{array}$ & & & & & & $\begin{array}{c}0.283^{* * * *} \\
(0.034)\end{array}$ \\
\hline
\end{tabular}


Table A2: Continued.

\begin{tabular}{|c|c|c|c|c|c|c|c|c|c|}
\hline & I & II & III & IV & V & VI & VII & VIII & IX \\
\hline \multicolumn{10}{|c|}{ Control variables } \\
\hline GER & $\begin{array}{c}0.233^{* * *} \\
(0.029)\end{array}$ & $\begin{array}{c}0.222^{* * *} \\
(0.030)\end{array}$ & $\begin{array}{c}0.205^{* * *} \\
(0.030)\end{array}$ & $\begin{array}{c}0.223^{* * *} \\
(0.029)\end{array}$ & $\begin{array}{c}0.210^{* * *} \\
(0.029)\end{array}$ & $\begin{array}{c}0.219 * * * \\
(0.029)\end{array}$ & $\begin{array}{c}0.216^{* * *} \\
(0.029)\end{array}$ & $\begin{array}{c}0.231^{* * *} \\
(0.030)\end{array}$ & $\begin{array}{c}0.211^{* * *} \\
(0.029)\end{array}$ \\
\hline FEM & $\begin{array}{c}-0.188^{* * * *} \\
(0.017)\end{array}$ & $\begin{array}{c}-0.185^{* * *} \\
(0.017)\end{array}$ & $\begin{array}{c}-0.191 \text { *** } \\
(0.017)\end{array}$ & $\begin{array}{c}-0.192 * * * \\
(0.017)\end{array}$ & $\begin{array}{c}-0.187 * * * \\
(0.017)\end{array}$ & $\begin{array}{c}-0.187 * * * \\
(0.017)\end{array}$ & $\begin{array}{c}-0.185 * * * \\
(0.017)\end{array}$ & $\begin{array}{c}-0.191 * * * \\
(0.017)\end{array}$ & $\begin{array}{c}-0.185 * * * \\
(0.017)\end{array}$ \\
\hline EDU_1 & $\begin{array}{c}0.254^{* * * *} \\
(0.023)\end{array}$ & $\begin{array}{c}0.244 * * * \\
(0.023)\end{array}$ & $\begin{array}{c}0.239 * * * \\
(0.024)\end{array}$ & $\begin{array}{c}0.263^{* * * *} \\
(0.023)\end{array}$ & $\begin{array}{c}0.265^{* * * *} \\
(0.023)\end{array}$ & $\begin{array}{c}0.269 * * * \\
(0.023)\end{array}$ & $\begin{array}{c}0.264 * * * \\
(0.023)\end{array}$ & $\begin{array}{c}0.268 * * * \\
(0.023)\end{array}$ & $\begin{array}{c}0.252 * * * \\
(0.023)\end{array}$ \\
\hline EDU_2 & $\begin{array}{c}0.520 * * * \\
(0.040)\end{array}$ & $\begin{array}{c}0.498 * * * \\
(0.040)\end{array}$ & $\begin{array}{c}0.488 * * * \\
(0.040)\end{array}$ & $\begin{array}{c}0.549 * * * \\
(0.040)\end{array}$ & $\begin{array}{c}0.548 * * * \\
(0.040)\end{array}$ & $\begin{array}{c}0.558 * * * \\
(0.040)\end{array}$ & $\begin{array}{c}0.548^{* * *} \\
(0.040)\end{array}$ & $\begin{array}{c}0.552 * * * \\
(0.040)\end{array}$ & $\begin{array}{c}0.509^{* * *} \\
(0.040)\end{array}$ \\
\hline EDU_3 & $\begin{array}{c}0.472 * * * \\
(0.032)\end{array}$ & $\begin{array}{c}0.455^{* * *} \\
(0.032)\end{array}$ & $\begin{array}{c}0.441^{* * *} \\
(0.032)\end{array}$ & $\begin{array}{c}0.507^{* * *} \\
(0.031)\end{array}$ & $\begin{array}{c}0.507^{* * *} \\
(0.031)\end{array}$ & $\begin{array}{c}0.514^{* * *} \\
(0.031)\end{array}$ & $\begin{array}{c}0.504^{* * * *} \\
(0.031)\end{array}$ & $\begin{array}{c}0.512 * * * \\
(0.031)\end{array}$ & $\begin{array}{c}0.463^{* * *} \\
(0.032)\end{array}$ \\
\hline CHI_1 & $\begin{array}{c}-0.061^{* * *} \\
(0.021)\end{array}$ & $\begin{array}{c}-0.060 * * * \\
(0.021)\end{array}$ & $\begin{array}{c}-0.059^{* * *} \\
(0.021)\end{array}$ & $\begin{array}{c}-0.072^{* * *} \\
(0.021)\end{array}$ & $\begin{array}{c}-0.072^{* * *} \\
(0.021)\end{array}$ & $\begin{array}{c}-0.071^{* * *} \\
(0.021)\end{array}$ & $\begin{array}{c}-0.071^{* * *} \\
(0.021)\end{array}$ & $\begin{array}{c}-0.070 * * * \\
(0.021)\end{array}$ & $\begin{array}{c}-0.057 * * * \\
(0.021)\end{array}$ \\
\hline CHI_2 & $\begin{array}{c}-0.087 * * * \\
(0.026)\end{array}$ & $\begin{array}{c}-0.087 * * * \\
(0.026)\end{array}$ & $\begin{array}{c}-0.088^{* * *} \\
(0.026)\end{array}$ & $\begin{array}{c}-0.094 * * * \\
(0.026)\end{array}$ & $\begin{array}{c}-0.097 * * * \\
(0.026)\end{array}$ & $\begin{array}{c}-0.095^{* * *} \\
(0.026)\end{array}$ & $\begin{array}{c}-0.096 * * * \\
(0.026)\end{array}$ & $\begin{array}{c}-0.097 * * * \\
(0.026)\end{array}$ & $\begin{array}{c}-0.084 * * * \\
(0.026)\end{array}$ \\
\hline CHI_3 & $\begin{array}{c}-0.317 * * * \\
(0.039)\end{array}$ & $\begin{array}{c}-0.310^{* * *} \\
(0.039)\end{array}$ & $\begin{array}{c}-0.307^{* * *} \\
(0.040)\end{array}$ & $\begin{array}{c}-0.333^{* * *} \\
(0.039)\end{array}$ & $\begin{array}{c}-0.329^{* * *} \\
(0.039)\end{array}$ & $\begin{array}{c}-0.331^{* * *} \\
(0.039)\end{array}$ & $\begin{array}{c}-0.327 * * * \\
(0.039)\end{array}$ & $\begin{array}{c}-0.331^{* * *} \\
(0.039)\end{array}$ & $\begin{array}{c}-0.308^{* * *} \\
(0.039)\end{array}$ \\
\hline AGE & $\begin{array}{c}-0.027 * * * \\
(0.001)\end{array}$ & $\begin{array}{c}-0.026^{* * *} \\
(0.001)\end{array}$ & $\begin{array}{c}-0.027 * * * \\
(0.001)\end{array}$ & $\begin{array}{c}-0.028 * * * \\
(0.001)\end{array}$ & $\begin{array}{c}-0.028^{* * *} \\
(0.001)\end{array}$ & $\begin{array}{c}-0.028 * * * \\
(0.001)\end{array}$ & $\begin{array}{c}-0.028^{* * *} \\
(0.001)\end{array}$ & $\begin{array}{c}-0.028^{* * *} \\
(0.001)\end{array}$ & $\begin{array}{c}-0.026^{* * *} \\
(0.001)\end{array}$ \\
\hline MAR & $\begin{array}{c}0.186 * * * \\
(0.020)\end{array}$ & $\begin{array}{c}0.192 * * * \\
(0.020)\end{array}$ & $\begin{array}{c}0.190 * * * \\
(0.020)\end{array}$ & $\begin{array}{c}0.187 * * * \\
(0.020)\end{array}$ & $\begin{array}{c}0.185^{* * *} \\
(0.020)\end{array}$ & $\begin{array}{c}0.187 * * * \\
(0.020)\end{array}$ & $\begin{array}{c}0.187 * * * \\
(0.020)\end{array}$ & $\begin{array}{c}0.183 * * * \\
(0.020)\end{array}$ & $\begin{array}{c}0.198 * * * \\
(0.020)\end{array}$ \\
\hline SEL & $\begin{array}{c}0.252^{* * *} \\
(0.060)\end{array}$ & $\begin{array}{c}0.249 * * * \\
(0.060)\end{array}$ & $\begin{array}{c}0.249 * * * \\
(0.060)\end{array}$ & $\begin{array}{c}0.264^{* * *} \\
(0.060)\end{array}$ & $\begin{array}{c}0.266^{* * *} \\
(0.060)\end{array}$ & $\begin{array}{c}0.269 * * * \\
(0.060)\end{array}$ & $\begin{array}{c}0.271^{* * *} \\
(0.060)\end{array}$ & $\begin{array}{c}0.268 * * * \\
(0.060)\end{array}$ & $\begin{array}{c}0.254^{* * *} \\
(0.060)\end{array}$ \\
\hline CIT & $\begin{array}{c}-0.132 * * * \\
(0.034)\end{array}$ & $\begin{array}{c}-0.134 * * * \\
(0.034)\end{array}$ & $\begin{array}{c}-0.131^{* * *} \\
(0.034)\end{array}$ & $\begin{array}{c}-0.139 * * * \\
(0.034)\end{array}$ & $\begin{array}{c}-0.140 * * * \\
(0.034)\end{array}$ & $\begin{array}{c}-0.137 * * * \\
(0.034)\end{array}$ & $\begin{array}{c}-0.134 * * * \\
(0.034)\end{array}$ & $\begin{array}{c}-0.126^{* * *} \\
(0.034)\end{array}$ & $\begin{array}{c}-0.138^{* * *} \\
(0.034)\end{array}$ \\
\hline EAS & $\begin{array}{c}-0.115^{* * * *} \\
(0.018)\end{array}$ & $\begin{array}{c}-0.115^{* * *} \\
(0.019)\end{array}$ & $\begin{array}{c}-0.110^{* * *} \\
(0.019)\end{array}$ & $\begin{array}{c}-0.134^{* * *} \\
(0.018)\end{array}$ & $\begin{array}{c}-0.137 * * * \\
(0.018)\end{array}$ & $\begin{array}{c}-0.134^{* * *} \\
(0.018)\end{array}$ & $\begin{array}{c}-0.132^{* * *} \\
(0.018)\end{array}$ & $\begin{array}{c}-0.122 * * * \\
(0.018)\end{array}$ & $\begin{array}{c}-0.113^{* * *} \\
(0.018)\end{array}$ \\
\hline \multicolumn{10}{|c|}{ Descriptive and test statistics } \\
\hline Obs. & 15,288 & 15,288 & 15,288 & 15,288 & 15,288 & 15,288 & 15,288 & 15,288 & 15,288 \\
\hline $\begin{array}{l}\text { Log- } \\
\text { Like. }\end{array}$ & $-129,884.6$ & $-129,864.7$ & $-129,837.9$ & $-129,913.5$ & $-129,914.1$ & $-129,926.4$ & $-129,914.9$ & $-129,921.6$ & $-129,869.1$ \\
\hline $\begin{array}{l}\text { LR test for } \\
\text { joint } \\
\text { significance }\end{array}$ & $\begin{array}{c}87.36 * * * \\
\text { (2) }\end{array}$ & $\begin{array}{c}127.15^{* * *} \\
(6)\end{array}$ & $\begin{array}{c}180.64^{* * * *} \\
(22)\end{array}$ & $\begin{array}{c}29.62 * * * \\
\text { (3) }\end{array}$ & $\begin{array}{c}28.34^{* * *} \\
\text { (3) }\end{array}$ & $\begin{array}{c}3.68 \\
(4)\end{array}$ & $\begin{array}{c}26.67 * * * \\
(4)\end{array}$ & $\begin{array}{c}13.33^{* * * *} \\
(4)\end{array}$ & $\begin{array}{c}118.26^{* * *} \\
(4)\end{array}$ \\
\hline $\begin{array}{l}\text { LR test for } \\
\text { intensity }\end{array}$ & & & $\begin{array}{c}53.49 * * * \\
(16)\end{array}$ & $\begin{array}{c}3.82 \\
(2)\end{array}$ & $\begin{array}{c}7.98 * * \\
(2)\end{array}$ & $\begin{array}{l}1.43 \\
(3)\end{array}$ & $\begin{array}{c}3.74 \\
(3)\end{array}$ & $\begin{array}{c}0.89 \\
(3)\end{array}$ & $\begin{array}{c}26.70^{* * *} \\
\text { (3) }\end{array}$ \\
\hline
\end{tabular}

Notes: Standard errors in parentheses. Degree of freedom in parentheses for LR tests. ${ }^{* * *} \mathrm{p}<0.01,{ }^{* *} \mathrm{p}<0.05, * \mathrm{p}<0.10$. 
Table A3: Estimation of coefficients for social capital and control variables with four types of subsamples.

\begin{tabular}{|c|c|c|c|c|c|c|c|c|}
\hline & $\mathrm{X}$ & XI & XII & XIII & XIV & $X V$ & XVI & XVII \\
\hline & \multicolumn{2}{|c|}{ by citizenship } & \multicolumn{2}{|c|}{ by gender } & \multicolumn{2}{|c|}{ by education } & \multicolumn{2}{|c|}{ by children } \\
\hline & GER $=1$ & else & $\mathrm{FEM}=1$ & else & EDU_0=1 & else & CHI_0=1 & else \\
\hline \multicolumn{9}{|c|}{ Social capital } \\
\hline MEE_D & $\begin{array}{c}0.224 * * * \\
(0.064)\end{array}$ & $\begin{array}{c}-0.063 \\
(0.179)\end{array}$ & $\begin{array}{c}0.197 * * \\
(0.093)\end{array}$ & $\begin{array}{c}0.214 * * * \\
(0.079)\end{array}$ & $\begin{array}{c}0.169 \\
(0.108)\end{array}$ & $\begin{array}{c}0.226 * * * \\
(0.072)\end{array}$ & $\begin{array}{c}0.258 * * * \\
(0.078)\end{array}$ & $\begin{array}{c}0.124 \\
(0.093)\end{array}$ \\
\hline HEL_D & $\begin{array}{c}0.087 * * \\
(0.038)\end{array}$ & $\begin{array}{c}0.074 \\
(0.087)\end{array}$ & $\begin{array}{c}0.072 \\
(0.047)\end{array}$ & $\begin{array}{c}0.076 \\
(0.053)\end{array}$ & $\begin{array}{c}-0.011 \\
(0.065)\end{array}$ & $\begin{array}{c}0.115^{* * *} \\
(0.042)\end{array}$ & $\begin{array}{c}0.056 \\
(0.046)\end{array}$ & $\begin{array}{c}0.106^{* *} \\
(0.054)\end{array}$ \\
\hline POL_D & $\begin{array}{c}-0.038 \\
(0.038)\end{array}$ & $\begin{array}{l}-0.013 \\
(0.142)\end{array}$ & $\begin{array}{l}-0.073 \\
(0.057)\end{array}$ & $\begin{array}{l}-0.000 \\
(0.048)\end{array}$ & $\begin{array}{l}-0.191 \\
(0.118)\end{array}$ & $\begin{array}{c}0.004 \\
(0.038)\end{array}$ & $\begin{array}{l}-0.030 \\
(0.049)\end{array}$ & $\begin{array}{l}-0.028 \\
(0.055)\end{array}$ \\
\hline VOL_D & $\begin{array}{c}0.053^{* *} \\
(0.024)\end{array}$ & $\begin{array}{l}-0.065 \\
(0.085)\end{array}$ & $\begin{array}{c}0.048 \\
(0.034)\end{array}$ & $\begin{array}{c}0.041 \\
(0.031)\end{array}$ & $\begin{array}{c}0.041 \\
(0.065)\end{array}$ & $\begin{array}{c}0.054^{* *} \\
(0.024)\end{array}$ & $\begin{array}{c}0.028 \\
(0.030)\end{array}$ & $\begin{array}{c}0.085^{* *} \\
(0.035)\end{array}$ \\
\hline REL_D & $\begin{array}{c}0.062 * * * \\
(0.022)\end{array}$ & $\begin{array}{c}-0.160 * * * \\
(0.055)\end{array}$ & $\begin{array}{c}0.019 \\
(0.028)\end{array}$ & $\begin{array}{l}0.054^{*} \\
(0.029)\end{array}$ & $\begin{array}{c}0.008 \\
(0.048)\end{array}$ & $\begin{array}{c}0.045^{* *} \\
(0.022)\end{array}$ & $\begin{array}{l}-0.006 \\
(0.027)\end{array}$ & $\begin{array}{c}0.087 * * * * \\
(0.030)\end{array}$ \\
\hline SPO_D & $\begin{array}{c}0.150 * * * \\
(0.019)\end{array}$ & $\begin{array}{l}0.110^{*} \\
(0.058)\end{array}$ & $\begin{array}{c}0.159 * * * \\
(0.026)\end{array}$ & $\begin{array}{c}0.135^{* * * *} \\
(0.025)\end{array}$ & $\begin{array}{c}0.197 * * * \\
(0.044)\end{array}$ & $\begin{array}{c}0.161^{* * *} \\
(0.019)\end{array}$ & $\begin{array}{c}0.158^{* * *} \\
(0.024)\end{array}$ & $\begin{array}{c}0.131^{* * *} \\
(0.027)\end{array}$ \\
\hline \multicolumn{9}{|c|}{ Control variables } \\
\hline GER & & & $\begin{array}{c}0.179 * * * \\
(0.045)\end{array}$ & $\begin{array}{c}0.263^{* * *} \\
(0.040)\end{array}$ & $\begin{array}{c}0.078 \\
(0.048)\end{array}$ & $\begin{array}{c}0.334 * * * \\
(0.040)\end{array}$ & $\begin{array}{c}0.254^{* * *} \\
(0.042)\end{array}$ & $\begin{array}{c}0.219 * * * \\
(0.042)\end{array}$ \\
\hline FEM & $\begin{array}{c}-0.196 * * * \\
(0.018)\end{array}$ & $\begin{array}{l}-0.079 \\
(0.053)\end{array}$ & & & $\begin{array}{c}-0.153^{* * *} \\
(0.041)\end{array}$ & $\begin{array}{c}-0.178^{* * *} \\
(0.019)\end{array}$ & $\begin{array}{c}-0.074 * * * \\
(0.022)\end{array}$ & $\begin{array}{c}-0.323^{* * *} \\
(0.026)\end{array}$ \\
\hline EDU_1 & $\begin{array}{c}0.287 * * * \\
(0.027)\end{array}$ & $\begin{array}{l}0.095^{*} \\
(0.056)\end{array}$ & $\begin{array}{c}0.266 * * * \\
(0.034)\end{array}$ & $\begin{array}{c}0.230 * * * \\
(0.032)\end{array}$ & & & $\begin{array}{c}0.256 * * * \\
(0.031)\end{array}$ & $\begin{array}{c}0.239 * * * \\
(0.036)\end{array}$ \\
\hline EDU_2 & $\begin{array}{c}0.538 * * * \\
(0.042)\end{array}$ & $\begin{array}{c}0.253 \\
(0.182)\end{array}$ & $\begin{array}{c}0.578 * * * \\
(0.056)\end{array}$ & $\begin{array}{c}0.422^{* * *} \\
(0.057)\end{array}$ & & & $\begin{array}{c}0.504 * * * \\
(0.050)\end{array}$ & $\begin{array}{c}0.485^{* * *} \\
(0.066)\end{array}$ \\
\hline EDU_3 & $\begin{array}{c}0.505^{* * *} \\
(0.035)\end{array}$ & $\begin{array}{l}0.173^{*} \\
(0.101)\end{array}$ & $\begin{array}{c}0.552 * * * \\
(0.044)\end{array}$ & $\begin{array}{c}0.371^{* * *} \\
(0.047)\end{array}$ & & & $\begin{array}{c}0.446 * * * \\
(0.042)\end{array}$ & $\begin{array}{c}0.482 * * * \\
(0.050)\end{array}$ \\
\hline CHI_1 & $\begin{array}{c}-0.065^{* * * *} \\
(0.022)\end{array}$ & $\begin{array}{c}0.001 \\
(0.066)\end{array}$ & $\begin{array}{c}-0.167 * * * \\
(0.029)\end{array}$ & $\begin{array}{c}0.025 \\
(0.031)\end{array}$ & $\begin{array}{l}-0.092^{*} \\
(0.050)\end{array}$ & $\begin{array}{c}-0.060^{* * *} \\
(0.023)\end{array}$ & & \\
\hline CHI_2 & $\begin{array}{c}-0.090 * * * \\
(0.028)\end{array}$ & $\begin{array}{l}-0.024 \\
(0.076)\end{array}$ & $\begin{array}{c}-0.196 * * * \\
(0.035)\end{array}$ & $\begin{array}{c}0.016 \\
(0.038)\end{array}$ & $\begin{array}{c}-0.071 \\
(0.063)\end{array}$ & $\begin{array}{c}-0.099 * * * \\
(0.028)\end{array}$ & & \\
\hline CHI_3 & $\begin{array}{c}-0.347 * * * \\
(0.044)\end{array}$ & $\begin{array}{l}-0.101 \\
(0.096)\end{array}$ & $\begin{array}{c}-0.504^{* * *} \\
(0.059)\end{array}$ & $\begin{array}{c}-0.165^{* * *} \\
(0.054)\end{array}$ & $\begin{array}{c}-0.255^{* * *} \\
(0.076)\end{array}$ & $\begin{array}{c}-0.343^{* * * *} \\
(0.046)\end{array}$ & & \\
\hline AGE & $\begin{array}{c}-0.027^{* * * *} \\
(0.001)\end{array}$ & $\begin{array}{c}-0.026^{* * *} \\
(0.003)\end{array}$ & $\begin{array}{c}-0.029 * * * \\
(0.001)\end{array}$ & $\begin{array}{c}-0.026^{* * *} \\
(0.001)\end{array}$ & $\begin{array}{c}-0.023^{* * *} \\
(0.002)\end{array}$ & $\begin{array}{c}-0.027 * * * \\
(0.001)\end{array}$ & $\begin{array}{c}-0.028^{* * *} \\
(0.001)\end{array}$ & $\begin{array}{c}-0.022 * * * \\
(0.002)\end{array}$ \\
\hline MAR & $\begin{array}{c}0.197 * * * \\
(0.021)\end{array}$ & $\begin{array}{c}0.157 * * \\
(0.066)\end{array}$ & $\begin{array}{c}0.145^{* * *} \\
(0.027)\end{array}$ & $\begin{array}{c}0.236 * * * \\
(0.030)\end{array}$ & $\begin{array}{c}0.192 * * * \\
(0.048)\end{array}$ & $\begin{array}{c}0.192 * * * \\
(0.022)\end{array}$ & $\begin{array}{c}0.203 * * * \\
(0.027)\end{array}$ & $\begin{array}{c}0.151^{* * *} \\
(0.029)\end{array}$ \\
\hline SEL & $\begin{array}{c}0.221 * * * \\
(0.062)\end{array}$ & $\begin{array}{c}0.703 * * * \\
(0.248)\end{array}$ & $\begin{array}{c}0.321 * * * \\
(0.088)\end{array}$ & $\begin{array}{c}0.171^{* *} \\
(0.083)\end{array}$ & $\begin{array}{c}0.499 * * \\
(0.211)\end{array}$ & $\begin{array}{c}0.283 * * * \\
(0.063)\end{array}$ & $\begin{array}{c}0.224 * * * \\
(0.082)\end{array}$ & $\begin{array}{c}0.278 * * * \\
(0.089)\end{array}$ \\
\hline CIT & $\begin{array}{c}-0.142 * * * \\
(0.036)\end{array}$ & $\begin{array}{l}-0.067 \\
(0.105)\end{array}$ & $\begin{array}{c}-0.133^{* * *} \\
(0.047)\end{array}$ & $\begin{array}{c}-0.141^{* * *} \\
(0.049)\end{array}$ & $\begin{array}{c}0.000 \\
(0.083)\end{array}$ & $\begin{array}{c}-0.137 * * * \\
(0.037)\end{array}$ & $\begin{array}{c}-0.157 * * * \\
(0.044)\end{array}$ & $\begin{array}{l}-0.079 \\
(0.053)\end{array}$ \\
\hline EAS & $\begin{array}{c}-0.114^{* * * *} \\
(0.019)\end{array}$ & $\begin{array}{l}-0.002 \\
(0.175)\end{array}$ & $\begin{array}{c}-0.206^{* * *} \\
(0.027)\end{array}$ & $\begin{array}{l}-0.029 \\
(0.026)\end{array}$ & $\begin{array}{c}-0.111^{* *} \\
(0.053)\end{array}$ & $\begin{array}{c}-0.133^{* * * *} \\
(0.020)\end{array}$ & $\begin{array}{c}-0.131 * * * \\
(0.024)\end{array}$ & $\begin{array}{c}-0.068^{* *} \\
(0.029)\end{array}$ \\
\hline Descripti & tistics & & & & & & & \\
\hline Obs. & 13,738 & 1,550 & 7,433 & 7,855 & 2,736 & 12,552 & 8,776 & 6,512 \\
\hline $\begin{array}{l}\text { Log- } \\
\text { Like. }\end{array}$ & $-115,217.4$ & $-9,733.7$ & $-57,627.7$ & $-61,891.0$ & $-18,345.8$ & $-104,672.5$ & $-69,537.8$ & $-50,113.5$ \\
\hline
\end{tabular}

Notes: Standard errors in parentheses. ${ }^{* * *} \mathrm{p}<0.01,{ }^{* *} \mathrm{p}<0.05,{ }^{*} \mathrm{p}<0.10$. 


\section{References}

Besedeš, Tibor and Prusa, Thomas J. (2006): "Product Differentiation and Duration of US Import Trade", Journal of International Economics, Vol. 70, No. 2, pp. 339-358.

Bickel, Peter J. and Doksum, Kjell A. (2015): Mathematical Statistics: Basic Ideas and Selected Topics, Boca Raton: CRC Press.

Bloch, Francis, Genicot, Garance and Ray, Debraj (2007): "Reciprocity in Groups and the Limits to Social Capital", American Economic Review, Vol. 97, No. 2, pp. 65-69.

Coleman, James S. (1988): "Social Capital in the Creation of Human Capital", American Journal of Sociology, Vol. 94, Supplement, pp. 95-120.

Coleman, James S. (1990): Foundations of Social Theory, Cambridge, MA: Harvard University Press.

Cox, David R. (1972): "Regression Models and Life-Tables", Journal of the Royal Statistical Society, Series B (Methodological), Vol. 34, No. 2, pp. 187-220.

Cramér, Harald (1999): Mathematical Methods of Statistics, Princeton: Princeton University Press.

Davidsson, Per and Honig, Benson (2003): "The Role of Social and Human Capital among Nascent Entrepreneurs", Journal of Business Venturing, Vol. 18, No. 3, pp. 301-331.

Dynarski, Mark and Sheffrin, Steven M. (1990): "The Behavior of Unemployment Durations over the Cycle", Review of Economics and Statistics, Vol. 72, No. 2, pp. 350-356.

Fan, C. Simon (2008): "Religious Participation and Children's Education: A Social Capital Approach", Journal of Economic Behavior and Organization, Vol. 65, No. 2, pp. 303-317.

Fox, Jonathan (1996): "How Does Civil Society Thicken? The Political Construction of Social Capital in Rural Mexico", World Development, Vol. 24, No. 6, pp. 1089-1103.

Francois, Patrick and Zabojnik, Jan (2005): "Trust, Social Capital, and Economic Development", Journal of the European Economic Association, Vol. 3, No. 1, pp. 51-94.

Freitag, Markus and Kirchner, Antje (2011): "Social Capital and Unemployment: A Macro-Quantitative Analysis of the European Regions", Political Studies, Vol. 59, No. 2, pp. 389-410.

Fukuyama, Francis (1995): "Social Capital and the Global Economy: A Redrawn Map of the World", Foreign Affairs, Vol. 74, No. 5, pp. 89-103.

Gertler, Paul, Levine, David I. and Moretti, Enrico (2006): "Is Social Capital the Capital of the Poor? The Role of Family and Community in Helping Insure Living Standards against Health Shocks", CESifo Economic Studies, Vol. 52, No. 3, pp. 455-499.

Glaeser, Edward L., Laibson, David and Sacerdote, Bruce (2002): "An Economic Approach to Social Capital", Economic Journal, Vol. 112, No. 483, pp. 437-458.

Gomez, Rafael and Santor, Eric (2001): "Membership Has Its Privileges: The Effect of Social Capital and Neighbourhood Characteristics on the Earnings of Microfinance Borrowers", Canadian Journal of Economics, Vol. 34, No. 4, pp. 943-966.

Greeley, Andrew (1997): "Coleman Revisited: Religious Structures as a Source of Social Capital", American Behavioral Scientist, Vol. 40, No. 5, pp. 587-594. 
Guiso, Luigi, Sapienza, Paola and Zingales, Luigi (2004): "The Role of Social Capital in Financial Development", American Economic Review, Vol. 94, No. 3, pp. 526-556.

Han, Aaron and Hausman, Jerry (1990): "Flexible Parametric Estimation of Duration and Competing Risk Models", Journal of Applied Econometrics, Vol. 5, No. 1, pp. 1-28.

Helliwell, John F. and Putnam, Robert D. (1995): "Economic Growth and Social Capital in Italy", Eastern Economic Journal, Vol. 21, No. 3, pp. 295-307.

Henrich, Joseph (2006): "Cooperation, Punishment, and the Evolution of Human Institutions", Science, Vol. 311, pp. 60-61.

Hess, Wolfgang and Persson, Maria (2012): "The Duration of Trade Revisited", Empirical Economics, Vol. 43, No. 3, pp. 1083-1107.

Hjorth, Urban (1980): "A Reliability Distribution with Increasing, Decreasing, Constant and Bathtub-Shaped Failure Rates", Technometrics, Vol. 22, No. 1, pp. 99-107.

Hosmer, David W., Lemeshow, Stanley and May, Susanne (2008): Applied Survival Analysis: Regression Modeling of Time to Event Data, Hoboken, NJ: Wiley.

Iyer, Sriya, Kitson, Michael and Toh, Bernard (2005): "Social Capital, Economic Growth and Regional Development", Regional Studies, Vol. 39, No. 8, pp. 1015-1040.

Kahn, Harold A. and Sempos, Christopher T. (1989): Statistical Methods in Epidemiology, New York: Oxford University Press.

Kalbfleisch, John D. and Prentice, Ross L. (2002): The Statistical Analysis of Failure Time Data, New York: Wiley.

Kiefer, Nicholas M. (1988): "Economic Duration Data and Hazard Functions", Journal of Economic Literature, Vol. 26, No. 2, pp. 646-679.

Knack, Stephen and Keefer, Philip (1997): "Does Social Capital Have an Economic Payoff? A Cross-Country Investigation", Quarterly Journal of Economics, Vol. 112, No. 4, pp. 1251-1288.

Kunze, Lars and Suppa, Nicolai (2014): "Bowling Alone or Bowling at all? The Effect of Unemployment on Social Participation", SOEPpapers on Multidisciplinary Panel Data Research, No. 703, pp. 1-50.

la due Lake, Ronald and Huckfeldt, Robert (1998): "Social Capital, Social Networks, and Political Participation", Political Psychology, Vol. 19, No. 3, pp. 567-584.

Nahapiet, Janine and Ghoshal, Sumantra (1998): "Social Capital, Intellectual Capital, and the Organizational Advantage", Academy of Management Review, Vol. 23, No. 2, pp. 242-266.

Narayan, Deepa and Pritchett, Lant (1999): "Cents and Sociability: Household Income and Social Capital in Rural Tanzania", Economic Development and Cultural Change, Vol. 47, No. 4, pp. 871-897.

Oh, Hongseok, Chung, Myung-Ho and Labianca, Giuseppe (2004): "Group Social Capital and Group Effectiveness: The Role of Informal Socializing Ties", Academy of Management Journal, Vol. 47, No. 6, pp. 860-875.

Putnam, Robert D. (1995): "Bowling Alone: America's Declining Social Capital", Journal of Democracy, Vol. 6, No. 1, pp. 65-78.

Routledge, Bryan R. and von Amsberg, Joachim (2003): "Social Capital and Growth", Journal of Monetary Economics, Vol. 50, No. 1, pp. 167-193. 
Ryan, Richard M. and Deci, Edward L. (2000): "Self-Determination Theory and the Facilitation of Intrinsic Motivation, Social Development, and Well-Being", American Psychologist, Vol. 55, No. 1, pp. 68-78.

Seippel, Ørnulf (2006): "Sport and Social Capital.” Acta Sociologica, Vol.49, No. 2, pp. 169-183.

Sobel, Joel (2002): "Can We Trust Social Capital?", Journal of Economic Literature, Vol. 40, No. 1, pp. 139-154.

Solow, Robert M. (2000): "Notes on Social Capital and Economic Performance", in: Dasgupta and Serageldin, pp. 6-12.

Stablein, Timothy (2011): "Helping Friends and the Homeless Milieu: Social Capital and the Utility of Sreet Peers", Journal of Contemporary Ethnography, Vol. 40, No. 3, pp. 290-317.

Tonts, Matthew (2005): "Competitive Sport and Social Capital in Rural Australia", Journal of Rural Studies, Vol. 21, No. 2, pp. 137-149.

Uysal, Selver D. and Pohlmeier, Winfried (2011): "Unemployment Duration and Personality", Journal of Economic Psychology, Vol. 32, No. 6, pp. 980-992.

Verhaeghe, Pieter-Paul and Tampubolon, Gindo (2012): "Individual Social Capital, Neighbourhood Deprivation, and Self-Rated Health in England", Social Science and Medicine, Vol. 75, No. 2, pp. 349-357.

Wagner, Gert G., Frick Joachim R. and Jürgen Schupp (2007): “The German Socio-Economic Panel Study (SOEP) Scope, Evolution and Enhancements”, Schmollers Jahrbuch Vol. 127, No. 1, pp. 139-169.

Weibull, Waloddi (1939): A Statistical Theory of the Strength of Materials, Stockholm: Generalstabens Litografiska Anstalts Förlag.

Westlund, Hans and Adam, Frane (2010): "Social Capital and Economic Performance: A Meta-Analysis of 65 Studies", European Planning Studies, Vol. 18, No. 6, pp. 893-919.

Wollebaek, Dag and Selle, Per (2002): "Does Participation in Voluntary Associations Contribute to Social Capital? The Impact of Intensity, Scope, and Type", Nonprofit and Voluntary Sector Quarterly, Vol. 31, No. 1, pp. 32-61.

Woolcock, Michael (1998): "Social Capital and Economic Development: Toward a Theoretical Synthesis and Policy Framework", Theory and Society, Vol. 27, No. 2, pp. 151-208.

Yamamura, Eiji (2010): "Effects of Interactions Among Social Capital, Income and Learning from Experiences of Natural Disasters: A Case Study from Japan", Regional Studies, Vol. 44, No. 8, pp. 1019-1032.

Yang, Guangbin (2007): Life Cycle Reliability Engineering, Hoboken, NJ: John Wiley and Sons.

Yli-Renko, Helena, Autio, Erkko and Tontti, Vesa (2002): "Social Capital, Knowledge, and the International Growth of Technology-Based New Firms", International Business Review, Vol. 11, No. 3, pp. 279-304. 